\title{
A new intramedullary sustained dynamic compression nail for the treatment of long bone fractures: a biomechanical study
}

\author{
Uzun kemik kırıklarının tedavisi için yeni bir intramedüller sürekli dinamik kompresyon çivisi: \\ Biyomekanik çalışma
}

\author{
Ahmet Karakaşlı, MD., İsmail Safa Satoğlu, MD., Hasan Havıtçıoğlu, MD. \\ Department of Orthopedics and Traumatology, Medical Faculty of Dokuz Eylül University, İzmir, Turkey
}

\begin{abstract}
Objectives: We developed a new intramedullary interlocking nail (sustained dynamic compressive nail; SDCN) which can sustain a continuous dynamic compressive force on the fracture edges to overcome implant failure, screw loosening and nonunion complications encountered in the traditionally used static intramedullary nailing (SIMN).
\end{abstract}

Materials and methods: Six pairs of composite femurs were fixed with SIMN and SDCN. The axial compression, bending, torsional stiffness, and strain values were analyzed.

Results: The mean axial compression stiffness values were $427.1 \mathrm{~N} / \mathrm{mm}$ for the SDCN and $217.8 \mathrm{~N} / \mathrm{mm}$ for SIMN, indicating a statistically significant difference $(\mathrm{p}=0.006)$. The mean stiffness values of rotation were $1.42 \mathrm{Nm} /{ }^{\circ}$ for the SDCN and $0.89 \mathrm{Nm} /{ }^{\circ}$ for SIMN. Anteroposterior bending tests were carried out. The mean results of stiffness were measured as 218 $\mathrm{N} / \mathrm{mm}$ for the SDCN and $182.7 \mathrm{~N} / \mathrm{mm}$ for the SIMN. The mean strain measurements in compression were $2454.5 \mu$-strain for the SDCN and $1123.8 \mu$-strain for the SIMN.

Conclusion: Biomechanically, the intramedullary SDCN is more stable than the SIMN system and it provides good abutment of the nail to the bone. Also, SDCN increases the stability by producing continuous compression and increasing the contact pressure of the fracture ends.

Keywords: Dynamic compression; fracture fixation; fractures; intramedullary.

An interlocking nail system with a stable static fixation technique is the gold standard treatment for the treatment of femoral shaft fractures. This technique has biomechanical superiority thanks to its more stable fixation and less soft tissue stripping than traditional plating techniques. ${ }^{[1-4]}$
Öz

Amaç: İmplant kırılmaları, vida gevşemeleri ve kaynamama komplikasyonlarını önlemek için geliştirdiğimiz kırık kemik uçlarına sürekli dinamik kompresyon yapabilen (sürekli dinamik kompresyon çivisi SDCN) yeni bir intramedüller çivi, geleneksel kilitli statik intramedüller çivi (SIMN) ile biyomekanik olarak karşılaştırıldı.

Gereç ve yöntemler: Altı çift kompozit sentetik femurun SDCN ve SIMN tespitleri yapıldı. Aksiyel kompresyon, bükülme, torsiyonel sertlik ve gerilme değerleri incelendi.

Bulgular: Ortalama aksiyel kompresyon sertlik değerleri SDCN için $427.1 \mathrm{~N} / \mathrm{mm}$ ve SIMN için $217.8 \mathrm{~N} / \mathrm{mm}$ idi; bu farklılık istatistiksel olarak anlamlı idi $(\mathrm{p}=0.006)$. Ortalama torsiyonel sertlik değerleri SDCN'de $1.42 \mathrm{Nm} /{ }^{\circ}$ ve SIMN'de $0.89 \mathrm{Nm} /{ }^{\circ}$ idi. Arka-ön bükülme testi yapıldı. Ortalama bükülme sertlik değeri SDCN için $218 \mathrm{~N} / \mathrm{mm}$, SIMN için $182.7 \mathrm{~N} / \mathrm{mm}$ olarak ölçüldü. Kompresyonda ölçülen ortalama gerilim değerleri SDCN için $2454.5 \mu$-strain, SIMN için $1123.8 \mu$-strain idi.

Sonuç: Biyomekanik olarak SDCN, SIMN'den daha stabildir ve kırık kemik uçlarına daha iyi temas sağlamaktadır. Ayrıca, SDCN sürekli kompresyon yaparak ve kırık uçlarındaki temas basıncını artırarak stabiliteyi artırır.

Anahtar sözcükler: Dinamik kompresyon; kırık sabitlenmesi; kırıklar; intramedüller.

However, fracture nonunion, which may cause an implant failure, is still a problem. ${ }^{[1,5,6]}$ Immediate or subsequent dynamization of an interlocking nail is regarded as an effective treatment for patients with fracture nonunion, particularly of hypertrophic types. $^{[1,7-11]}$ Several studies have demonstrated that

- Received: December 04, 2014 Accepted: March 09, 2015

- Correspondence: Ahmet Karakaşlı, MD. Dokuz Eylül Üniversitesi Tıp Fakültesi Ortopedi ve Travmatoloji Anabilim Dalı, 35340 Alsancak, İzmir, Turkey. Tel: +90 232 - 4123353 Fax: +90 232 - 2772277 e-mail: karakasliahmet@gmail.com 
stress is exceptionally high at the distal interlocking screws or holes of the nail, leading to mechanical failure of the implant and loss of fixation or fracture nonunion. ${ }^{[10,12,13]}$ Interlocking intramedullary rod systems are widely used; however it may produce rotational instability and fixed gap at the fracture site. The stress bypasses the gap from bone to implant, leading to possible implant failures such as screw or rod breakage, therefore, nonunion is the frequent result in many cases. ${ }^{[12,13]}$

Recently, experimental studies showed that timing of union after intramedullary nailing is influenced by the motion at the fracture gap and demonstrated that relatively rigid constructs lead to earlier fracture healing. ${ }^{[6]}$ Compression at the fracture site enhances fracture healing in terms of mineralization of the fracture gap and mechanical properties at mid-term and at the time of union compared with statically fixed bones. ${ }^{[14-16]}$ According to the Wolff's law, narrow gap, rigid fixation and sustained dynamic compression are essential for bone healing. ${ }^{[17-20]}$

In the earlier studies, researchers concluded that the dynamization technique should be performed by removing the most distal locking screw from the fracture site. Unfortunately, there is no mechanical evidence to prove the efficacy of such an approach. ${ }^{[1]}$ Therefore, we developed a new intramedullary sustained dynamic compressive nail (SDCN) to provide a continuous sustained compression at the fracture site. In our study, we report an experimental assessment of the implant design and compared it with the statically fixed standard intramedullary nail (SIMN).

\section{MATERIALS AND METHODS}

\section{Artificial femur nailing technique, osteotomy}

We used six pairs of composite femur models ( $4^{\text {th }}$ Generation, Sawbones ${ }^{\circledR}, \quad \# 3403$, Vashon, Washington, USA, European Department in Sweden) with a length of $400 \mathrm{~mm}$ from the piriformis fossa to the intercondylar notch. Artificial femurs were used, as they have more consistent geometry and material properties. This allowed standardization of the materials and structures for the biomechanical comparative studies. The diaphysis portion of the femur had only cortices. At the metaphyseal region, there were cortices and polyurethane foam simulating cancellous bone. The nails were inserted after over-reaming the medulla of intact femurs by $1 \mathrm{~mm}$. The osteotomies, then, were created by using oscillating saw. An osteotomy located at $20 \mathrm{~mm}$ above the isthmus representing a situation with short nail-cortical contact. The entry portal of the nails was at the piriformis fossa. After inserting the nails and confirming that they were properly positioned, all locking screws were applied under an external guide attached to the proximal nail end.

Two kinds of intramedullary nails were compared in a randomized pair-match design. One was the commercially available standard 10x340 mm SIMN (Tipsan Joint Stock Company, Izmir, Turkey) which was locked with screws both proximally and distally. The other one was our newly designed SDCN of the same size which is manufactured and produced by the same company (Tipsan Joint Stock Company, Izmir, Turkey). The nail has a potential to generate a compression force of $400 \mathrm{~N}$. This compression force and shortening of the bone can be adjusted by the surgeon during surgery. The SDCN, shown schematically in Figure 1, consists of an outer hollow cylinder SDCN shaft. The proximal end houses an adjustment screw and the SDCN is formed by a metal sheath in the form of a tube. The dynamic system is placed inside this hollow cylindrical tube. The distal part of the dynamic system, which is $2 \mathrm{~mm}$ smaller in radius, can move inside and outside of the proximal tube. The compression spring is adjusted using the (a)

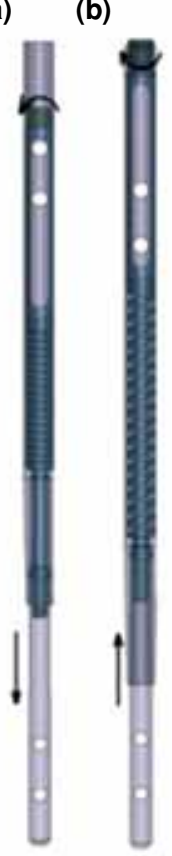

(c)

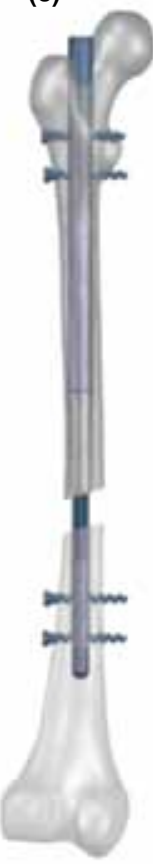

(d)

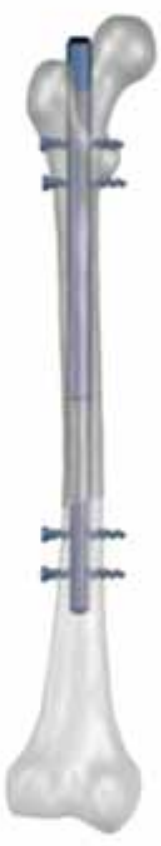

Figure 1. Schematic drawings of nailing mechanism. (a) The view of established system before application. (b) The view of the system activated during application.

(c) Stage of the implantation of the system to the bone.

(d) The view of the system which was activated after fixation. 
proximal screw before the nail is placed into the bone medullary canal. While adjusting the proximal screw, the length of the nail gets longer. Following the placement of the nail inside the intramedullary cavity, the locking screws are placed and a continuous compression is provided on the fractured ends by loosening the proximal adjustment screw. Each nail system was inserted into six femoral bone models and was fixed tow distal and tow proximal locking screws.

\section{Mechanical tests}

All the tests were performed with a Shimadzu AG-IS $10 \mathrm{kN}$ model test machine (Shimadzu Corporation, Kyoto, Japan). The femoral bone models were fixed to the load cell of the test machine. The vertical load was applied to the femoral head with a hemi-cylindrical cup which allowed medial translation of the femoral head during loading (Figure 2). Initially, a loading of $100 \mathrm{~N}$ was given with a loading rate of $10 \mathrm{~mm} / \mathrm{min}$; this was repeated several times until the load deformation relationship was stabilized. Then the femur-nail constructs were loaded up to $750 \mathrm{~N} \cdot{ }^{[21-23]}$ In all tests the change in axial, bending and torsional angles were recorded both in loaded and unloaded states. Because of the small sample sizes, the statistical analysis of this study was conducted with the Mann-Whitney U test as well as SPSS for Windows version 15.0 software program (SPSS Inc., Chicago, IL, USA).

\section{Axial compression testing}

The nail-bone construct was tested under axial loading with the femoral head in compression and the condyles were seated in physiological position. Prior to the test, a non-contact CCD camera extensometers (Non- contact Video Extensometer DVE-101/201, Shimadzu, Japan) was used. $5 \mathrm{~N}$ the axial test, a preload of $5 \mathrm{~N}$ and a maximal load of $750 \mathrm{~N}$ were applied and, then, reduced to $0 \mathrm{~N}$ while simultaneously recording the vertical displacement and the strain. Displacement was detected by the rotary linear variable differential transformer in the testing machine, and strain was detected by an extensometer. The test velocity was $0.1 \mathrm{~mm} / \mathrm{s}$. Each side was loaded for three cycles. The weight of one leg is approximately $10-15 \%$ of the body weight. The weight of one leg of a person with $80 \mathrm{~kg}$ body weight approximately is equal to $8-10 \mathrm{~kg}{ }^{[18,19]}$ The leg is lifted and moved forward in the swing phase of walking. Meanwhile, in a person with femur fracture, the leg is distracted with approximately a force of $80-100 \mathrm{~N}$ by the distal part of the fracture during walking. ${ }^{[24]}$ In this study, a distraction force of $100 \mathrm{~N}$ was applied for both SIMN and SDCN. During axial loading, the strain was measured by the strain-gauges placed at the fractured ends.

\section{Four-point bending testing}

A four-point bending model was used for the anterior posterior $(\mathrm{AP})$, posterior anterior (PA)
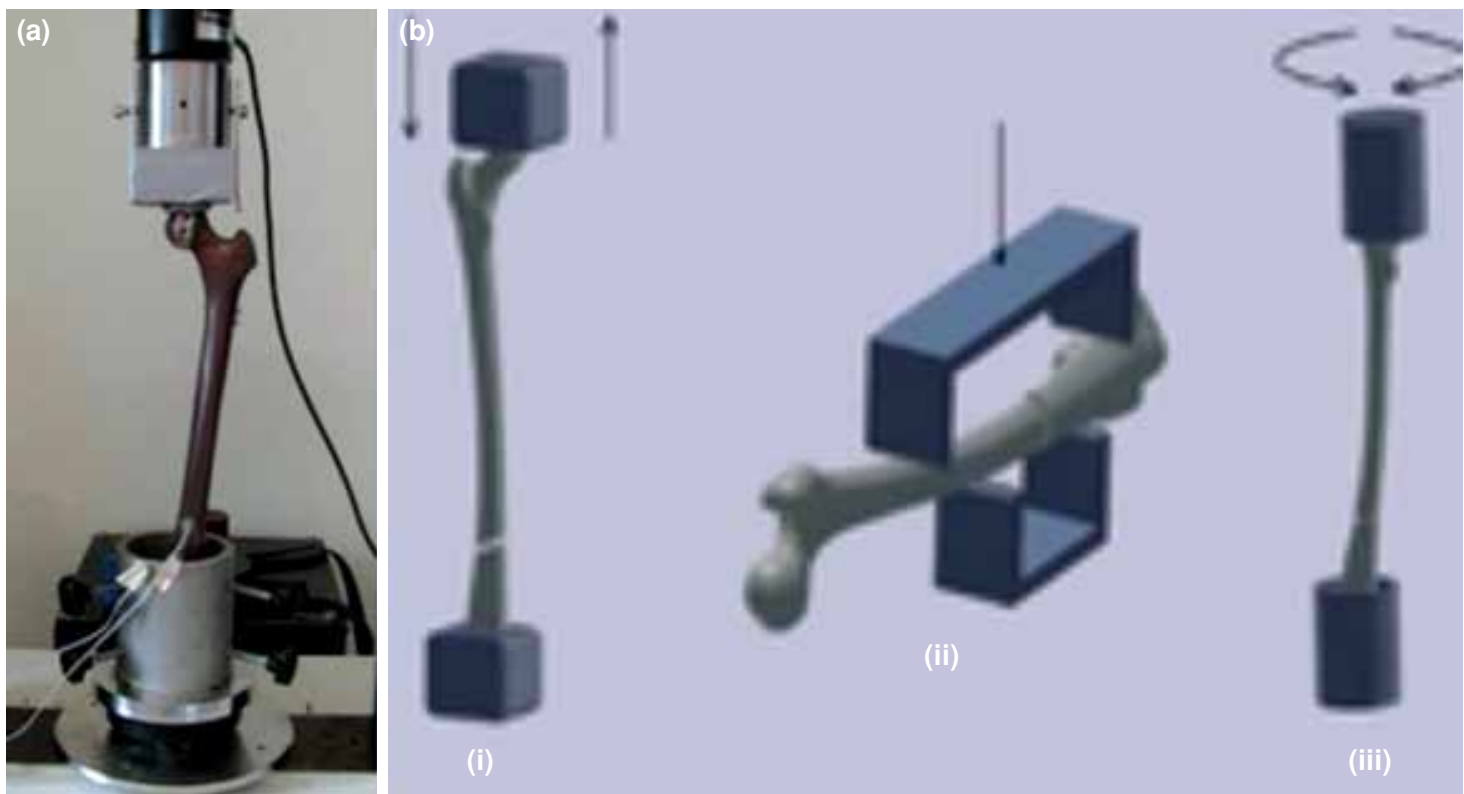

Figure 2. (a) Potted specimen prepared for mechanical tests. Figure showing the specimen placed in the load cell of the testing machine. Strain-gauges are placed on the sawbone femur's fracture contact points. (b) Schematic drawings of the tests. (i) Testing of potted bone-implant axial compression and distraction. (ii) Testing of A-P, P-A, $\mathrm{L}-\mathrm{M}, \mathrm{M}-\mathrm{L}$ four-point bending and (iii) testing of rotation. The arrows demonstrate the loading directions. 
TABLE I

Mean values of displacements

\begin{tabular}{|c|c|c|}
\hline & SIMN & SDCN \\
\hline & Mean & Mean \\
\hline Axial compression (mm) & 3.68 & 1.83 \\
\hline Distraction $(\mathrm{mm})$ & 1.78 & 0.178 \\
\hline Rotation $(+8)\left({ }^{\circ}\right)$ & 9.28 & 5.68 \\
\hline Rotation $(-8)\left({ }^{\circ}\right)$ & 9.15 & 5.73 \\
\hline Bending AP (mm) & 1.73 & 1.46 \\
\hline Bending PA (mm) & 1.28 & 1.32 \\
\hline Bending lateral (mm) & 1.01 & 1.25 \\
\hline Bending medial (mm) & 1.23 & 1.7 \\
\hline
\end{tabular}

SIMN: Static intramedullary nailing; SDCN: Sustained Dynamic Compressive Nail; AP: Anterior posterior; PA: Posterior anterior.

(sagittal plane), medial-lateral (ML), and lateralmedial (LM) (coronal plane) testing. In each bending test, a maximal load of $300 \mathrm{~N}$ was applied at $0.1 \mathrm{~mm} / \mathrm{s}$. Centering the device with reference to the center of the fracture zone, all the time was ensured that the bending moment was applied to the same location in each specimen as close as possible. The test was repeated three times to ensure the reproducibility of the results. The load versus displacement values were recorded to calculate the bending stiffness and flexibility and displacement was measured.

\section{Torsional testing}

Torsion test was carried out with servo sync torque machine (SQM132, ELSIM Elektroteknik A.S, Istanbul, Turkey). The torsion tests were conducted in the displacement control mode with a constant axial load of $10 \mathrm{~N}$ to simulate resting muscle tension and a maximum moment of $8 \mathrm{Nm}$ in both directions; the

\section{TABLE II}

Mean values of stiffness

\begin{tabular}{lcccc}
\hline & \multicolumn{2}{c}{ SIMN } & & SDCN \\
\cline { 2 - 2 } & Mean \pm SD & & Mean \pm SD \\
\hline Axial compression $(\mathrm{N} / \mathrm{mm})$ & $217.8 \pm 68.2$ & & $427.1 \pm 98.6$ \\
Distraction $(\mathrm{N} / \mathrm{mm})$ & & $-75.9 \pm 61.6$ & & $-677.7 \pm 317$ \\
Rotation $(+8)\left(\mathrm{Nm} /{ }^{\circ}\right)$ & & $0.89 \pm 0.1$ & & $1.42 \pm 0.1$ \\
Rotation $(-8)\left(\mathrm{Nm} /{ }^{\circ}\right)$ & $0.92 \pm 0.2$ & & $1.41 \pm 0.1$ \\
Bending AP $(\mathrm{N} / \mathrm{mm})$ & & $182.7 \pm 46.5$ & & $218 \pm 57.4$ \\
Bending PA $(\mathrm{N} / \mathrm{mm})$ & & $239.3 \pm 38.3$ & & $269.7 \pm 120.8$ \\
Bending lateral $(\mathrm{N} / \mathrm{mm})$ & & $303.4 \pm 57.8$ & & $250.1 \pm 59$ \\
Bending medial $(\mathrm{N} / \mathrm{mm})$ & & $272.3 \pm 103.2$ & & $194.3 \pm 60.6$ \\
Strain maximum $(\mu$-strain) & $1123.8 \pm 66.6$ & & $2454.5 \pm 45.1$ \\
Strain minimum $(\mu$-strain) & 0 & & 400.83 \\
\hline
\end{tabular}

SIMN: Static intramedullary nailing; SDCN: Sustained Dynamic Compressive Nail; SD: Standard deviation; AP: Anterior posterior; PA: Posterior anterior. premoment was $0 \mathrm{Nm}$ and the test velocity was $0.3 \%$ s. The testing cycle went from $0-8 \mathrm{Nm}$ and all the way through $8 \mathrm{Nm}$ in the other direction back to $0 \mathrm{Nm}$. Torque versus the degree of angle deformation values were recorded.

\section{RESULTS}

\section{Axial compression test}

The mean values of stiffness results are shown in Table I. Axial compression tests were carried out for SDCN and the SIMN. Under axial load, the mean stiffness value was $427.1 \mathrm{~N} / \mathrm{mm}$ for the SDCN (Table II). In addition, axial compression mean values of displacement were $1.83 \mathrm{~mm}$ for the SDCN, $3.68 \mathrm{~mm}$ for the SIMN, respectively (Table I). However, the mean value of stiffness was $217.8 \mathrm{~N} / \mathrm{mm}$ for SIMN, respectively (Figure 3 ). These results showed that the SDCN was more rigid than the SIMN under axial load. It indicated a statistically significant difference between the groups $(p=0.006)$.

\section{Distraction test}

For comparison, distraction tests were performed on both nails. In the distraction tests for the SDCN the mean stiffness was measured as $677.7 \mathrm{~N} / \mathrm{mm}$ (Table II). Also, the distraction mean values of displacement were $0.178 \mathrm{~mm}$ for the SDCN, $1.78 \mathrm{~mm}$ for the SIMN (Table I). The mean stiffness values for the SIMN were $75.9 \mathrm{~N} / \mathrm{mm}$ (Figure 3). The results showed that the SDCN was more rigid than SIMN, suggesting a statistically significant difference between the groups $(\mathrm{p}=0.004)$.

\section{Rotation test}

Rotation tests were carried out for SDCN and SIMN. First a torsional force of $+8 \mathrm{~N} / \mathrm{m}$ was applied.

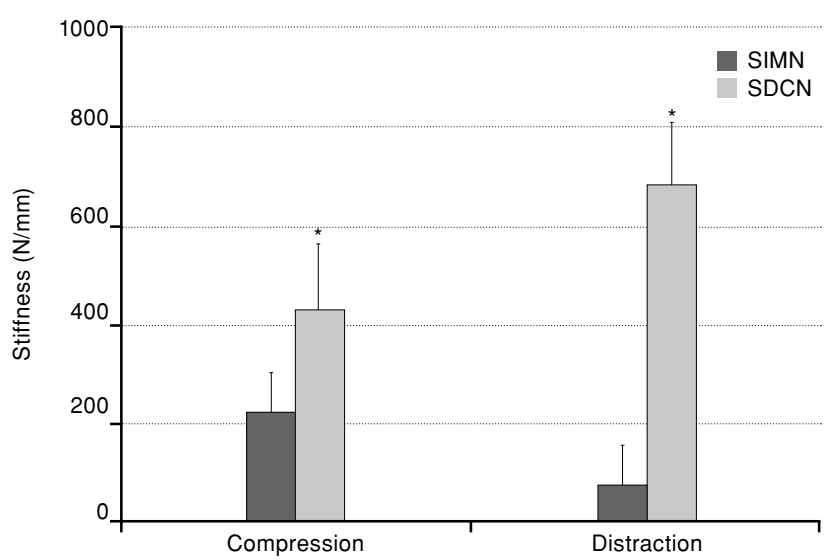

Figure 3. The mean stiffness of Sustained Dynamic Compressive Nail (SDCN) and static intramedullary nailing (SIMN) in axial compression-distraction, and different types of nailing techniques. 


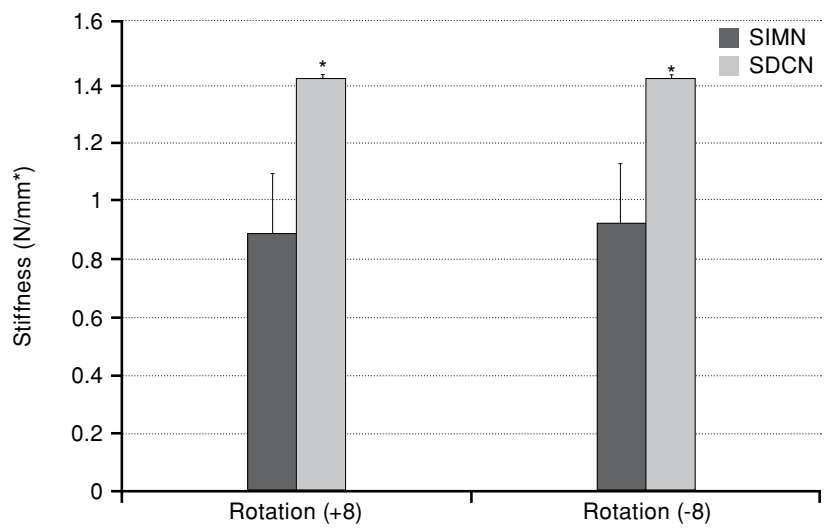

Figure 4. Torsional stiffness during rotational loading in clockwise and counter-clockwise of femur-nail constructs. SDCN: Sustained dynamic compressive nail; SIMN: Static intramedullary nailing.

According to these test results, the mean stiffness values of rotation was $1.42 \mathrm{Nm} /{ }^{\circ}$ for the SDCN and $0.89 \mathrm{Nm} /{ }^{\circ}$ for SIMN (Table II). For SDCN, the mean degree was measured as $5.68^{\circ}$ and $9.28^{\circ}$ for SIMN (Table I). The results have shown us that SDCN has a more rigid rotational stability than SIMN. This difference was statistically significant between the groups $(p=0.004)$. The results obtained after applying $-8 \mathrm{Nm}$ rotational mean stiffness values were $1.41 \mathrm{Nm} /{ }^{\circ}$ for SDCN and $0.92 \mathrm{Nm} /{ }^{\circ}$ for SIMN (Figure 4). In addition to this, the mean degree was measured $5.73^{\circ}$ for SDCN and $9.15^{\circ}$ for SIMN. The rotational rigidity for SDCN was more than that of SIMN, indicating a statistically significant difference $(\mathrm{p}=0.01)$.

\section{Bending tests}

Anteroposterior bending tests were carried out. The mean results of stiffness were measured as

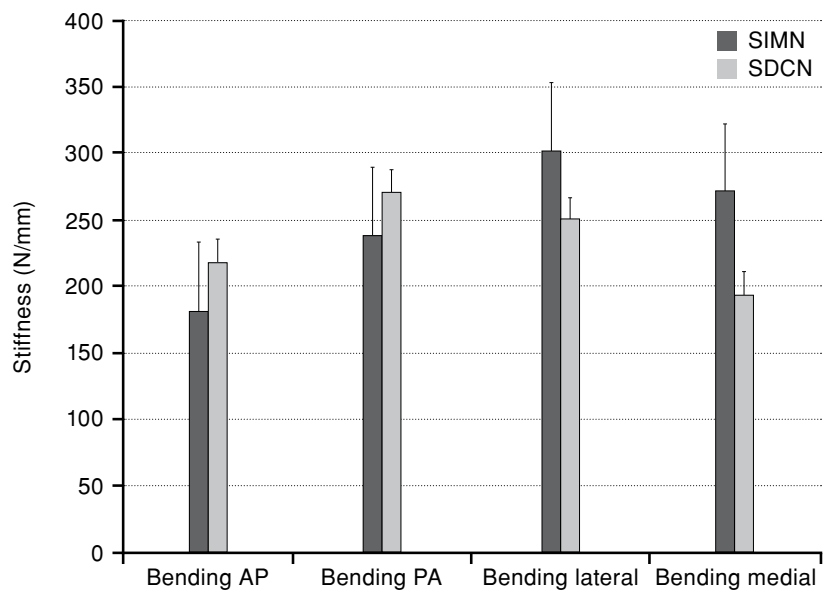

Figure 5. Bending stiffness in different positions of femur-nail constructs. Bending stiffness measurements for all femur models showed no statistically significant differences between the measured data. SDCN: Sustained dynamic compressive nail; SIMN: Static intramedullary nailing.
$218 \mathrm{~N} / \mathrm{mm}$ for SDCN and $182.7 \mathrm{~N} / \mathrm{mm}$ for SIMN. The mean stiffness results of the posterior-anterior bending tests were measured as $269.7 \mathrm{~N} / \mathrm{mm}$ for SDCN and $139.3 \mathrm{~N} / \mathrm{mm}$ for SIMN. In the lateral bending tests the results of mean stiffness were $250.1 \mathrm{~N} / \mathrm{mm}$ for SDCN and $303.4 \mathrm{~N} / \mathrm{mm}$ for SIMN (Figure 5). In the medial bending tests the results of mean stiffness were maximum $194.3 \mathrm{~N} / \mathrm{mm}$ for SDCN and $272.3 \mathrm{~N} / \mathrm{mm}$ for SIMN. All bending test results of SDCN and SIMN are shown in Table II. In addition, there was no significant difference between SIMN and SDCN nails in all bending directions in the displacement measurements (Table I). The compression values of SDCN and SIMN were measured by using strain gauge. Under axial loading, the results of mean strain measurements were $2454.5 \mu$-strain for the SDCN and $1123.8 \mu$-strain for the SIMN (Figure 6). In addition, the value of SDCN mean strain was $400.83 \mu$-strain without axial compression loading. The tension value of the SDCN was higher than that of SIMN, suggesting a statistically significant difference $(p=0.004)$.

\section{DISCUSSION}

In the present study, we aimed to evaluate the biomechanical properties of a newly designed intramedullary interlocking nail which sustains a dynamic compression on fracture edges for long bone fracture fixation. The design of the nail was intended to overcome the most commonly encountered complications of the well-known static interlocking nails. Therefore, we performed a comparative biomechanical assessment between the SDCN and a commercially available static interlocking nail device.

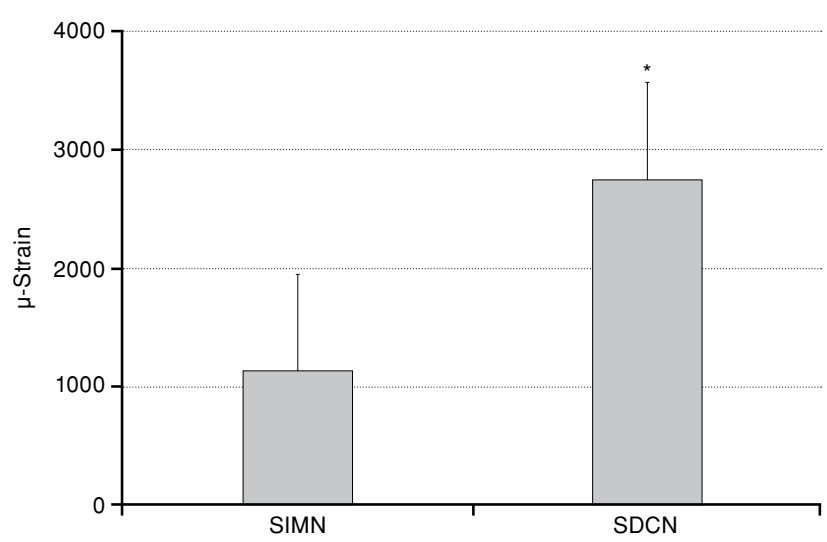

Figure 6. Sustained dynamic compressive nail (SDCN) and static intramedullary nailing (SIMN) strain during loading between two groups of femur-nail constructs. The space under the strain of SDCN bar is $400.83 \mu$-strain which represents sustained compression on the system without any external force. 
The new sustained dynamic compression device fixation technique resulted in significantly smaller fracture gaps and generated better contact pressure than the static fixation technique. Thus, the body weight can be transferred from the proximal fragment to the distal fragment and the fractured femur can share the stress with the interlocking nail system via the fracture site. From a clinical point of view, a smaller fracture gap and sufficient contact pressure are key factors in improving the healing rate.

A static interlocking nail system is often selected to treat fractured femurs, since this system can provide sufficient fixation stability and can prevent limb shortening. ${ }^{[1,25]}$ However, the static fixation technique can result in a gap between fracture fragments which is a serious disadvantage of this technique. ${ }^{[1]}$ Compressive loading for bone healing is still controversial in the literature. In previous experimental studies $300 \mathrm{~N}, 500 \mathrm{~N}, 700 \mathrm{~N}$ and one and half times of body weight compressive loading have been suggested for bone healing. ${ }^{[26-30]}$

In our study, it was possible to use $400 \mathrm{~N}$ compressive loading. In addition to this, $750 \mathrm{~N}$ loading was used to represent body weight and total load was equal to approximately one and half times of body weight. Gardner et al. ${ }^{[26]}$ showed that increased load magnitude was coupled with higher strain rates to maintain a constant loading. Higher strain rates would be expected to increase bone healing. Meanwhile, the distal part of the femur fracture induced a distraction of approximately $100 \mathrm{N.} \cdot{ }^{[2]}$ This distraction force might increase the gap. In our study, a distraction force equal to $100 \mathrm{~N}$ was applied to both SDCN and SIMN. The gap increases were $0.18 \mathrm{~mm}$ for SDCN and $1.78 \mathrm{~mm}$ for SIMN, indicating a statistically significant difference $(p=0.004)$. Maintained compressive force during the first six weeks produced a higher amount of new bone formation. Higher amount of periosteal new bone formation was observed ${ }^{[31-33]}$ Shortening of fracture gaps by compression can improve the healing process. Thus the main effect of this procedure is the reduction of the fracture gap distance, which is known to improve the bone healing. ${ }^{[34-36]}$ In the axial compression loading, a slight micro movement was recorded at the fracture site with SDCN. However, the movement recorded at the fracture site was more with SIMN compared to SDCN. The reason for the little micro motion in SDCN is sustained compression of $400 \mathrm{~N}$ at the fracture ends. This compression narrows the gap considerably. The contact pressure increases and the gap narrows at the fracture site. Thus, the micromotions with SDCN $(1.83 \mathrm{~mm})$ are much less than those of SIMN $(3.68 \mathrm{~mm})$. This difference in micromotions was statistically significant between the groups $(p=0.006)$. It also supports increased stability and load sharing between the nail and the bone. As a result, the nail and screw failure rate may decrease. The problem of locking screw failure and nail breakage has been described after using intramedullary nails. In a large series, $13.8 \%$ failure rate of nails and screws was reported, which was treated with small diameter nails and large gaps. ${ }^{[34,37]}$ Better rotational stability was also observed for SDCN, indicating a statistically significant difference $(p=0.004)$. Continuous compression increases the contact pressure of the fracture ends which in term increases rotational stability. Drosos et al. ${ }^{[38]}$ showed that fractures reduced with a bony contact area of $50 \%$ or more of the diaphyseal diameter, irrespective of the presence of comminution or not, showed significantly higher torsional stability than fractures with a contact area of less than $50 \%$.

Furthermore, mechanical strain should be in the range of 100-2,000 $\mu$-strain for bone healing. ${ }^{[39-41]}$ Under compressive loading 400 to 2,465 $\mu$-strain was recorded at the synthetic bone fracture site with SDCN. This value is consistent with the literature data. The strain ranges between 0 to $600 \mu$-strain with SIMN. Strain falls to zero may cause delayed unions or non-union. In a traditional perspective, dynamization is provided by removing proximal or distal interlocking screws in SIMN. In the absence of sufficient callus tissue formed or in the presence of multi-fragmented fractures, a rotational instability or shortening may result. With over shortening, the nail penetrates the knee joint. ${ }^{[1]}$

However, a dynamic compression is provided without removing the interlocking screws with SDCN. Thus, similar displacement values were recorded in four-point bending tests with both nails. There was not any statistically significant difference. With SDCN the distal part can move in the proximal part in axial direction and the distal part is $2 \mathrm{~mm}$ thinner than the proximal part. Although SDCN provides continued axial compression, the results of four point tests were similar to that of SIMN.

Despite its biomechanical advantages of SDCN, its biological and clinical behaviors are still to be elucidated. It is necessary to conduct animal studies with SDCN to learn its biological behavior and in vivo stability.

\section{Conclusion}

We conclude that the SDCN is an effective femoral fracture fixation device. The technique displays mechanical stability which is superior to that of the standard SIMN in axial compression and 
torsion in the laboratory setting. Furthermore, little micro-movement was recorded at the fracture site with SDCN in the axial compression loading. The compression is sustained in SDCN, even in lying or sitting positions. Continuous dynamic compression provides $\mu$-strain for bone healing without removing the interlocking screws for dynamization with SDCN. Thus, the formation of axial and rotational instability is prevented. Continuous compression increases the contact pressure of the fracture ends which in term may increase the stability.

\section{Declaration of conflicting interests}

The authors declared no conflicts of interest with respect to the authorship and/or publication of this article.

\section{Funding}

The authors received no financial support for the research and/or authorship of this article.

\section{REFERENCES}

1. Shih KS, Hsu CC, Hsu TP. A biomechanical investigation of the effects of static fixation and dynamization after interlocking femoral nailing: a finite element study. J Trauma Acute Care Surg 2012;72:46-53.

2. Steinberg EL, Keynan O, Sternheim A, Drexler M, Luger E. Treatment of diaphyseal nonunion of the femur and tibia using an expandable nailing system. Injury 2009;40:309-14.

3. Gelalis ID, Politis AN, Arnaoutoglou CM, Korompilias $\mathrm{AV}$, Pakos EE, Vekris MD, et al. Diagnostic and treatment modalities in nonunions of the femoral shaft: a review. Injury 2012;43:980-8.

4. Demirtaş A, Azboy I, Durakbaşa MO, Uçar BY, Mercan AS, Cakır IA. The relationship between the quadriceps muscle strength and the anterior knee pain occurring after locked intramedullary nailing for tibial diaphysis fractures. [Article in Turkish] Eklem Hastalik Cerrahisi 2011;22:81-4.

5. Lenz M, Gueorguiev B, Richards RG, Mückley T, Hofmann GO, Höntzsch D, et al. Fatigue performance of angle-stable tibial nail interlocking screws. Int Orthop 2013;37:113-8.

6. Karapınar H, Akgün U, Kazımoğlu C, Bulut T, Sener M. Ilizarov augmentation in the treatment of humeral shaft nonunions developing after failed intramedullary nailing. [Article in Turkish] Eklem Hastalik Cerrahisi 2010;21:142-6.

7. Brumback RJ, Virkus WW. Intramedullary nailing of the femur: reamed versus nonreamed. J Am Acad Orthop Surg 2000;8:83-90.

8. Schüller M, Weninger P, Tschegg E, Jamek M, Redl H, Stanzl-Tschegg S. Micromotion at the fracture site after tibial nailing with four unreamed small-diameter nails--a biomechanical study using a distal tibia fracture model. J Trauma 2009;66:1391-7.

9. Sen RK, Senthil Kumar R, Aggarwal S, Nagi OS. The use of iliac crest strut graft for forearm nonunion gaps in 10 patients: Nicoll's technique revisited. Eklem Hastalik Cerrahisi 2005;16:36-41.
10. Ricci WM, Gallagher B, Haidukewych GJ. Intramedullary nailing of femoral shaft fractures: current concepts. J Am Acad Orthop Surg 2009;17:296-305.

11. Weninger P, Schueller M, Jamek M, Stanzl-Tschegg S, Redl $\mathrm{H}$, Tschegg EK. Factors influencing interlocking screw failure in unreamed small diameter nails--a biomechanical study using a distal tibia fracture model. Clin Biomech (Bristol, Avon) 2009;24:379-84.

12. Eveleigh RJ. A review of biomechanical studies of intramedullary nails. Med Eng Phys 1995;17:323-31.

13. Jagodzinski M, Krettek C. Effect of mechanical stability on fracture healing--an update. Injury 2007;38:3-10.

14. Doblaré M, García JM, Gomez J. Modelling bone tissue fracture and healing: a review. J Eng Fract Mech 2004;71:1809-40.

15. Wähnert D, Hoffmeier K, Fröber R, Hofmann GO, Mückley T. Distal femur fractures of the elderly--different treatment options in a biomechanical comparison. Injury 2011;42:655-9.

16. Lavini F, Dall'Oca C, Bartolozzi P. Bone transport and compression-distraction in the treatment of bone loss of the lower limbs. Injury 2010;41:1191-5.

17. Chen JH, Liu C, You L, Simmons CA. Boning up on Wolff's Law: mechanical regulation of the cells that make and maintain bone. J Biomech 2010;43:108-18.

18. Aydin K, Sahin V, Gürsu S, Mercan AS, Demir B, Yildirim T. Effect of pentoxifylline on fracture healing: an experimental study. Eklem Hastalik Cerrahisi 2011;22:160-5.

19. Tsubota K, Suzuki Y, Yamada T, Hojo M, Makinouchi A, Adachi T. Computer simulation of trabecular remodeling in human proximal femur using large-scale voxel FE models: Approach to understanding Wolff's law. J Biomech 2009;42:1088-94.

20. Boyle C, Kim IY. Three-dimensional micro-level computational study of Wolff's law via trabecular bone remodeling in the human proximal femur using design space topology optimization. J Biomech 2011;44:935-42.

21. Karakaşlı A, Yıldız DV, Kumtepe E, Kızmazoğlu C, Havitçığlu H. Biomechanical comparison of intact lumbar lamb spine and endoscopic discectomized lamb spine. Eklem Hastalik Cerrahisi 2013;24:33-8.

22. Dailey HL, Daly CJ, Galbraith JG, Cronin M, Harty JA. A novel intramedullary nail for micromotion stimulation of tibial fractures. Clin Biomech (Bristol, Avon) 2012;27:182-8.

23. Wang G, Pan T, Peng X, Wang J. A new intramedullary nailing device for the treatment of femoral shaft fractures: a biomechanical study. Clin Biomech (Bristol, Avon) 2008;23:305-12.

24. Schneider E, Michel MC, Genge M, Zuber K, Ganz R, Perren SM. Loads acting in an intramedullary nail during fracture healing in the human femur. J Biomech 2001;34:849-57.

25. Okcu G, Aktuglu K. Antegrade nailing of femoral shaft fractures combined with neck or distal femur fractures. A retrospective review of 25 cases, with a follow-up of 36-150 months. Arch Orthop Trauma Surg 2003;123:544-50.

26. Gardner MJ, van der Meulen MC, Demetrakopoulos D, Wright TM, Myers ER, Bostrom MP. In vivo cyclic axial compression affects bone healing in the mouse tibia. J Orthop Res 2006;24:1679-86.

27. Checa S, Prendergast PJ, Duda GN. Inter-species investigation of the mechano-regulation of bone healing: comparison of secondary bone healing in sheep and rat. J Biomech 2011;44:1237-45. 
28. Lee K, Maxwell A, Lanyon LE. Validation of a technique for studying functional adaptation of the mouse ulna in response to mechanical loading. Bone 2002;31:407-12.

29. De Souza RL, Matsuura M, Eckstein F, Rawlinson SC, Lanyon LE, Pitsillides AA. Non-invasive axial loading of mouse tibiae increases cortical bone formation and modifies trabecular organization: a new model to study cortical and cancellous compartments in a single loaded element. Bone 2005;37:810-8.

30. Epari DR, Duda GN, Thompson MS. Mechanobiology of bone healing and regeneration: in vivo models. Proc Inst Mech Eng H 2010;224:1543-53.

31. Epari DR, Schell H, Bail HJ, Duda GN. Instability prolongs the chondral phase during bone healing in sheep. Bone 2006;38:864-70.

32. Skerry TM. The response of bone to mechanical loading and disuse: fundamental principles and influences on osteoblast/osteocyte homeostasis. Arch Biochem Biophys 2008;473:117-23.

33. Claes L, Augat P, Schorlemmer S, Konrads C, Ignatius A, Ehrnthaller C. Temporary distraction and compression of a diaphyseal osteotomy accelerates bone healing. J Orthop Res 2008;26:772-7.

34. Papakostidis C, Psyllakis I, Vardakas D, Grestas A, Giannoudis PV. Femoral-shaft fractures and nonunions treated with intramedullary nails: the role of dynamisation.
Injury 2011;42:1353-61.

35. Chao EY, Inoue N. Biophysical stimulation of bone fracture repair, regeneration and remodelling. Eur Cell Mater 2003;6:72-84

36. Aydin K, Sahin V, Gürsu S, Mercan AS, Demir B, Yildirim T. Effect of pentoxifylline on fracture healing: an experimental study. Eklem Hastalik Cerrahisi 2011;22:160-5.

37. Duda GN, Mandruzzato F, Heller M, Goldhahn J, Moser $\mathrm{R}$, Hehli $\mathrm{M}$, et al. Mechanical boundary conditions of fracture healing: borderline indications in the treatment of unreamed tibial nailing. J Biomech 2001;34:639-50.

38. Drosos G, Karnezis IA, Bishay M, Miles AW. Initial rotational stability of distal tibial fractures nailed without proximal locking: the importance of fracture type and degree of cortical contact. Injury 2001;32:137-43.

39. Mavčič B, Antolič V. Optimal mechanical environment of the healing bone fracture/osteotomy. Int Orthop 2012;36:689-95.

40. Thompson MS, Epari DR, Bieler F, Duda GN. In vitro models for bone mechanobiology: applications in bone regeneration and tissue engineering. Proc Inst Mech Eng $\mathrm{H}$ 2010;224:1533-41.

41. Ignatius A, Blessing $H$, Liedert A, Schmidt C, NeidlingerWilke C, Kaspar D, et al. Tissue engineering of bone: effects of mechanical strain on osteoblastic cells in type I collagen matrices. Biomaterials 2005;26:311-8. 